\title{
Acupressure Technique to Reduce Dysmenorrhea
}

 \\ yanisatudua@gmail.com
}

\begin{abstract}
Background: Dysmenorrhea or menstrual pain was one of the most common complaints in young women who come to the clinic or doctor. As many as $90 \%$ of Indonesian women had experienced menstrual pain. Non-pharmacological therapy that can be used to reduce menstrual pain, one of them was by used the acupressure technique. The purpose of this study was to Determine Whether acupressure was effective in reducing menstrual pain.
\end{abstract}

Methods: The type of research used quasy-experiment. This study used the One Pretest-Posttest Group design. The total samples taken in this study were 31 female students of SMK Negeri 1 Rembang. The Data collected in this study was primary data. The sampling technique used Accidental-Sampling. The statistical test used the Wilcoxon test.

Results: The results of this study indicate that there was an effect of acupressure effective in reducing menstrual pain in SMK Negeri 1 Rembang with a value of $p$ value 0,000 .

Conclusion: From the results of this study it was expected that the female students of make acupressure technique as a way to reduce menstrual pain.

Keyword : Acupressure; Dysmenorrhea

1,2,3) Poltekkes Kemenkes Semarang, Indonesia

Jl. Tirtoagung, Pedalangan, Banyumanik

Background. Adolescence was a period of transition from childhood to adulthood, usually from the age of $10-18$ years (Minister of Health Affairs, 2014). Physical changes in adolescence is marked by a growth spurt. Acceleration of growth can be seen from the increase in height which reached $90 \%$ to $95 \%$, weight gain, which reached $95 \%$ and the accretion of fat tissue occurs because of hormonal changes in the body (Soetjiningsih, 2012). One was the biological physical changes girls start menstruating or menstruation (Kumalasari et al, 2012).

Menstruation was a natural cycle that occurs on a regular basis to prepare a woman's body every month to pregnancy. The menstrual cycle involves several stages that are controlled by the interaction of hormones released by the hypothalamus, pituitary and ovaries front (Anurogo \& Wulandari, 2011). Complaints that often arise during menstruation was easy to have an enlarged and interference with regard to period in the form of dysmenorrhea (Manuaba, 2012).

Dysmenorrhea or painful menstruation was one of the most common complaints in young women who come to the clinic or doctor. Almost all women experience discomfort during menstruation such a bad taste the lower abdomen and is usually accompanied by nausea, dizziness, and even fainting.

The prevalence of dysmenorrhea in the United States an estimated $45-90 \%$. The high numbers are assumed from a variety of symptoms that have not been reported. Dysmenorrhea is also responsible for absenteeism at work and school, as many as $13-51 \%$ of women have been absent at least once and $5-14 \%$ repeatedly absent (Anurogo \& Wulandari, 2011) .In the epidemiological studies in the adolescent population (aged 12-17 years) in the United States, Klein and Litt dysmenorrhea reported a prevalence of $59.7 \%$. Of those who complain of pain, $12 \%$ severe pain, $37 \%$ moderate and $49 \%$ mild pain. The study also reported that $14 \%$ of dysmenorrhea cause young women are often absent from school (Anurogo \& Wulandari, 2011).

Conditions in Indonesia, more women who experience menstrual pain did not report or pay a visit to the doctor. Such a shame to see a doctor and a tendency to underestimate the disease often make the data in the Indonesian people with certain diseases can not be ascertained. $90 \%$ of women in Indonesia had experienced menstrual pain (Anurogo \& Wulandari, 2011). Menstrual pain or dysmenorrhea needs to be addressed 
because it can make women unable to move normally and require medication or special handling (Anurogo \& Wulandari, 2011). Pain management approach includes both pharmacological and non-pharmacological.

In pain management there are other ways to relieve the pain in addition to the use of medication (Smeltzer and Bare, 2013). Many ways to eliminate or decrease menstrual pain, both pharmacological and non-pharmacological. For pharmacological treatment using pain relief drugs, not everyone will accept the chemical compounds in the body, even the few who experience hypersensitivity or allergy, that will cause new problems. Non pharmacological management safer to use because it does not cause side effects such as drug- medicines (Ning, 2011).

Non-pharmacological therapy which can be used to reduce menstrual pain as Transcutaneous Electrical Nerve Stimulation (TENS) acupuncture and acupressure or massage the meridian points of the body, because the technique of acupressure is an alternative that is easy, safe, and does not require any fees or expenses compared with other techniques. (Morgan \& Hamilton, 2003). (Hasanah, 2010) by using point Taichong (LR3), the results of this study, the reduction in pain intensity was 1.03 points after being given acupressure therapy. (Julianti, 2011) In addition, several points can be used, among others, point SP6 (Chen \& Chen 2004), Hoku point / He-qu (LI4) (Mahoney, 1993)

Acupressure is one kind or manner of traditional health care skills that carried through suppression techniques on the surface of the body at acupuncture points with fingers or other body parts or tools are bluntended for the purpose of health care (MoH RI, 2015) .Strategic plan in 2015-2019 Ministry of Health has set a target achievement indicators of traditional health service delivery. As for the target of $75 \%$ of the number of existing health centers in 2019 has developed a traditional health care. One of the achievement indicators measured by the ability of community health centers move to carry out self care utilization acupressure. Government rule No. 103 of 2014 Article 70, where people are directed to be able to do health care on their own (self care) implemented by skills. Self care utilization acupressure is an effort to maintain and improve the health status and prevent and resolve problems or mild health problems independently by individuals, families, groups, and communities.

Preliminary studies were done in SMK Negeri 1 Rembang Purbalingga there were $37(25.1 \%)$ students did not experience menstrual pain, $56 \quad(38.1 \%)$ students experienced mild pain, $30(20.4 \%)$ students experiencing moderate pain, 18 (11.9) students experienced severe pain, and 6 (4.1\%) students experienced a very severe pain. Visit data book UKS 2018 in SMA N 1 Rembang Purbalingga of 173 students are $(9.8 \%)$ students who experience menstrual pain, whereas of the 140 students at SMP N 1 Rembang Purbalingga traffic data UKS book contained $(7.8 \%)$ students who experience menstrual pain, and 105 students at SMP N 2 Rembang Purbalingga traffic data contained UKS book (10\%) of students who experience menstrual pain. Treatment of menstrual pain in adolescents become an attraction because of the number of incidents of menstrual pain is higher than other age groups. Menstrual pain in adolescents is very distracting to learn and may also indicate abnormalities in the reproductive system and should receive special attention. Handling of menstrual pain in SMK N 1 Rembang with the number of students who experience menstrual pain most of the majority use of pharmacological therapy is to give analgesic medication to relieve pain.

In this study, researchers wanted to give a non-pharmacological therapy action by acupressure because the acupressure technique is an alternative therapy that is easy, safe and require no fees or expenses compared with other techniques. Based on the description above, researchers are interested to take the title of "Effectiveness Acupressure to reduce menstrual pain"

Methods. The research is quasy Experiment. This study uses a model of "One Group Pretest-Posttest". Subjects in this study were all young women in class $X$ in SMK N 1 Rembang month of March-April 2019 amounted to 31 students. Samples taken in this study were students who experience menstrual pain in March to April 2019 at SMK N 1 Rembang. Total samples taken in this study is 31 students.

In this study, the instrument used is the observation sheet. Where in the observation 
sheets are filling date, code of respondents, Numeric Rating Scale pain scale before and after acupressure.In this case the researchers checked on a pain scale of perceived pain scale ranging from 0 to 10 pain

Analysis of the data used in this research is to use analysis of univariate and bivariate analysis. Data is said to be normal if $p>0.05$. Univariate analysis in this study is used to describe the frequency distribution of respondents menstrual pain levels both before and after do acupressure. Bivariate analysis were performed on This research included a comparative study (comparing).

Result and Discussion. The measurement results menstrual pain scale before acupressure can be seen in the table below:

Table 1. Frequency Distribution of Respondents by Menstrual Pain Scale before Acupressure in SMK N1 Apex.

\begin{tabular}{lll}
\hline Skala nyeri & Frekuensi & Prosentase \\
\hline 0 & 4 & $12,90 \%$ \\
1 & 8 & $25,80 \%$ \\
2 & 9 & $29,03 \%$ \\
3 & 5 & $16,12 \%$ \\
4 & 3 & $9,67 \%$ \\
5 & 1 & $3,22 \%$ \\
6 & 1 & $3,22 \%$ \\
7 & 0 & $0 \%$ \\
8 & 0 & $0 \%$ \\
9 & 0 & $0 \%$ \\
10 & 0 & $0 \%$ \\
\hline Total & 31 & $100 \%$ \\
\hline
\end{tabular}

Table 1 shows from 31 respondents with menstrual pain scale before treatment acupressure. Based on the table it can be concluded most respondents experiencing pain. The table above shows the highest number of respondents pain scale 9 by 2 respondents $(6.45 \%)$, and the most experienced painful menstrual pain on a scale of 5 with a frequency of up to 8 respondents $(25.8 \%)$. The fewest respondents experiencing menstrual pain with pain scale 2 and 3 pain scale with the frequency of each one of the respondents (3.22\%). Menstrual pain scale measurement results after doing acupressure can be seen in the table below:
Table 2. Distribution of respondents by Menstrual Pain Scale after doing Acupressure in SMK N 1 Rembang.

\begin{tabular}{lll}
\hline Skala nyeri & Frekuensi & Prosentase \\
\hline 0 & 0 & $0 \%$ \\
1 & 0 & $0 \%$ \\
2 & 1 & $3,22 \%$ \\
3 & 1 & $3,22 \%$ \\
4 & 4 & $12,90 \%$ \\
5 & 8 & $25,80 \%$ \\
6 & 7 & $22,58 \%$ \\
7 & 3 & $9,67 \%$ \\
8 & 5 & $16,12 \%$ \\
9 & 2 & $6,45 \%$ \\
10 & 0 & $0 \%$ \\
\hline Total & 31 & $100 \%$ \\
\hline
\end{tabular}

Table 2 above shows the most number of respondents decreased menstrual pain on a pain scale 2 with a frequency of up to 9 respondents $(29.03 \%)$. While respondents were the least experienced menstrual pain with pain scale 5 and 6 with the frequency of each one of the respondents (3.22\%).

Table 3. Differences Menstrual Pain Scale before and after acupressure in SMK N 1 Rembang.

\begin{tabular}{|c|c|c|c|c|}
\hline \multicolumn{5}{|l|}{ Ranks } \\
\hline & & $N$ & $\begin{array}{l}\text { Mean } \\
\text { Rank }\end{array}$ & $\begin{array}{l}\text { Sum of } \\
\text { Ranks }\end{array}$ \\
\hline \multirow[t]{4}{*}{$\begin{array}{l}\text { post_test - } \\
\text { pre_test }\end{array}$} & $\begin{array}{l}\text { Negative } \\
\text { Ranks }\end{array}$ & $31^{a}$ & 16.00 & 496.00 \\
\hline & $\begin{array}{l}\text { Positive } \\
\text { Ranks }\end{array}$ & $0^{\mathrm{b}}$ & .00 & .00 \\
\hline & Ties & $0^{c}$ & & \\
\hline & Total & 31 & & \\
\hline \multicolumn{5}{|c|}{ Test Statistics ${ }^{b}$} \\
\hline & & & \multicolumn{2}{|c|}{ post_test - pre_tes } \\
\hline $\bar{Z}$ & & & \multicolumn{2}{|l|}{$-4.905^{a}$} \\
\hline$P$ value & & & \multicolumn{2}{|c|}{.000} \\
\hline
\end{tabular}


Table 4 Test Statistics

\begin{tabular}{|c|c|c|c|c|c|}
\hline \multicolumn{6}{|c|}{ Paired Samples Statistics } \\
\hline & & Mean & $N$ & $\begin{array}{l}\text { Std. } \\
\text { Deviatio } \\
n\end{array}$ & $\begin{array}{l}\text { Std. } \\
\text { Error } \\
\text { Mean }\end{array}$ \\
\hline \multirow{2}{*}{ Pair 1} & Pretest & 5.77 & 31 & 1.802 & .324 \\
\hline & Postest & 2.06 & 31 & 1.482 & .266 \\
\hline
\end{tabular}

From the analysis using the Wilcoxon test with a computer program show that the table Ranks known Negative Ranks = 31 means a pain scale that decreased pain scale before and after as many as 31 respondent, Ties $=0$ means the pain scale fixed before and after acupressure as 0 respondents while Positive Ranks $=0$ means no increased scale increased pain before and after acupressure.

Conclusion and Suggestions. The results show the comparison scale data processing menstrual pain experienced by the respondents before and after akupresure. In the statistical test shows that the scale of menstrual pain decreased significantly. Statistical test results showed that $Z=-4905$ $x 4905$ means that acupressure was more effective in reducing menstrual pain and $p=$ 0.001 . Because the value of $p<0.05$, statistically there was a significant difference between the pain scale before and after acupressure or can be inferred was $\mathrm{Ha}$ accepted.

Acknowledgements. Thanks to the researchers say to all those who have helped in completing this research.

\section{References}

Acupoint for the Treatment of Primary Dysmenorrhea: A Meta-Analysis online. Available. (Http://www.hindawi.com) [March 7, 2015]

Amanda P, Nimas Ayu., 2018. Akupresure Easy Ways to Overcome Dysmenorrhea. (Wordpres.com)

Anurogo Dito, Ari Wulandari. 2011. How accurate cope with menstrual pain. Andi Offset.
Anna, LK 2014. Self Massage Akupresure for Sendiri.Online.Tersedia (http://www.kompas.com). [March 10th 2015]

Ariska, Ria Julianti. 2014. Effects of Therapy Minimizes Akupresure in Dysmenorrhea in a Young Women in SMAN 1 Pekalongan

Blogger, Asdah., 2017 Sp 6. Sanyianjio / Sin Yin Ciao (Three Yin Intersection point). (Www.terapijarum.com)

Chen, et al. 2013. Acupunture or Acupresure at the Sanjinyio (SP6)

Dahlan, Asmita, Tri Veni Syahminan. Effect of Warm Compress Therapy Against Menstrual Pain. Endurance Journal 2 (1), February 2017.

Efriyanti, Et.All.2015. Effect of Therapeutic Acupressure Sanyinjiao Point Of Primary Dysmenorrhea Pain Intensity In Viii Semester Student Nursing Science Program. Coping Nurses Journal ISSN: 2303-1298 Vol. 3 \# 2, May-August, 2015 7

UB's Faculty of Nursing Malang.Tersedia (http://www.unbrau.com). [March 9, 2015]

Kashefi, et al. 2010. Effect of ocupressure at the Sanyinjiao point on primary dysmenorrhea a randommized controlled trial. On line. Available (http://www.ncbi.nlm.nih.gov/ PubMed). [March 7, 2015]

Julianti, 2014. Effectiveness Against Akupresure Dysmenorrhea In Young Women. Jom PSIK Vol 1, 2

MoH RI. 2011. Practical help Toga and Akupresure.

$\mathrm{MoH}$ RI. 2015. Adolescent Reproductive Health Situation. Data and information Center.

Julianti, et.all, 2014. Effectiveness Against akupressur Disminore In Young 
Women. Jom PSIK VOL.1 NO.2 October 2014

Journal of Nursing. 2016. Measurement Pain Scale. (M.facebook.com / Emergency Critical Care17 / Posts / 109,041,811,071,766). (January 30, 2019)

East Lampung. Scientific Writing (KTI) tanjungkarang polytechnic, Metro Midwifery Studies Program. Unpublished. Metro

Megawati, et al. Effect of Aroma Therapy Relaxation With Intensity Changes Against Disminore. Journal of Nursing, 2016

Manuaba. 2012. Obstetrics, Gynecology, and KB. Book Medical Publishers. Jakarta

Mardiatun, 2013. Effect of Acupressure In Disminore Minimizing Primer On The Young Women In Nursing Department of the Ministry of Health polytechnic Polytechnic Mataram 2013. MoH Journal Mataram
Rahayu, Asri, et al. Influence Endhorpine Disminore Message Against Pain, Journal of Midwives' Midwife Jurnal'Volume 3 No. 02, July 2017.

Ridwan And Herlina. 2015 Method of Acupressure To Relieve Menstrual Pain. Metro Health Journal Volume Sai Wawai viii Issue 1 June 2015, ISSN: 19779-469x

Saputra, K. 2017. Basic Acupuncture. Airlangga University Perss. Surabaya.

Saputra, K., S Sudirman. 2009. Pain With Acupuncture For Neurosain approach. Sugeng Seto, Surabaya.

Sriwahyuni, Endang. 2011. Effectiveness of Therapy Akupresure in Minimizing 